A Hora do liXo: Literatura enCOMENDADA DE Clarice LisPector

Juliana Gervason DefiLipPo*

\title{
RESUMO
}

Este artigo tem por objetivo discutir a questão cultural presente na construção e recepção da obra $A$ via crucis do corpo, de Clarice Lispector, utilizando-se, para tanto, do conceito de cultura adotado por Terry Eagleton. A intenção do trabalho é apontar o quanto a obra em estudo diverge da produção da escritora numa tentativa de adequar-se a um momento cultural específico.

PalaVRas-ChAVE: Literatura, cultura, Clarice Lispector.

INTRODUÇÃO

Poder-se-ia pensar que esta ideologia voltada para o público consumidor fosse característica de uma arte dispendiosa como o cinema, porém, GustavoDahl enuncia que "mercado é cultura", sem o saber ele expressa uma realidade que transcende a esfera cinematográfica e que se refere ao domínio cultural como um todo, ao Espírito de uma época.

Renato ORTIZ

Escritores dificilmente se orgulham de obras encomendadas. Essa afirmação seria suficiente para descartar quaisquer observações ou análises a respeito de $A$ via crucis do corpo, publicada por Clarice Lispector, em 1974. A obra encomendada pela editora Artenova pretendia aproveitar o sucesso literário que o nome da escritora carregava no mercado editorial.

* Doutoranda na Universidade Federal de Juiz de Fora (Juiz de Fora, MG).

E-mail: defiju@acessa.com 
Além disso, Clarice, nos anos 70, trabalhava como tradutora da Artenova e dentre as traduções realizadas nesse período constam obras da escritora francesa Emmanuelle Arsan. Em 1975, por exemplo, surge nas livrarias Novelas da erosfera, livro traduzido por Clarice do original francês publicado em 1969. Trata-se de uma literatura erótica que causou grande furor literário na época. Assim, tanto a tradução realizada por Clarice para a Artenova, como a obra encomendada, estão inseridas num contexto cultural extremamente consumidor desse tipo de produto.

A idéia da encomenda dos contos eróticos, como a própria escritora explica numa das primeiras páginas do livro, era que a obra tratasse de assuntos específicos. Nessa "Explicação”, Clarice, que então contava com a publicação de 14 livros e estava com 53 anos de idade, sente a necessidade de pedir desculpas aos leitores:

O poeta Álvaro Pacheco, meu editor na Artenova, me encomendou três histórias que, disse ele, realmente aconteceram. Os fatos eu tinha, faltava a imaginação. E era assunto perigoso. Respondi-lhe que não sabia fazer história de encomenda. Mas - enquanto ele me falava ao telefone - eu já sentia nascer em mim a inspiração. Comecei no sábado. No domingo de manhã as três histórias estavam prontas: "Miss Algrave", "O Corpo" e "Via Crucis". Eu mesma espantada. Todas as histórias deste livro são contundentes. E quem mais sofreu fui eu mesma. Fiquei chocada com a realidade. Se há indecências nas histórias a culpa não é minha. Inútil dizer que não aconteceram comigo, com minha família e com meus amigos. Como é que sei? Sabendo. Artistas sabem das coisas. Quero apenas avisar que não escrevo por dinheiro e sim por impulso. Vão me jogar pedras. Pouco importa. Não sou de brincadeiras, sou mulher séria. Além do mais tratava-se de um desafio.

Hoje é dia 12 de maio, Dia das Mães. Não fazia sentido escrever nesse dia histórias que eu não queria que meus filhos lessem porque eu teria vergonha. Então disse ao editor: só publico sob pseudônimo. Até já tinha escolhido um nome bastante simpático: Cláudio Lemos. Mas ele não aceitou. Disse que eu devia ter liberdade de escrever o 
que quisesse. Sucumbi. Que podia fazer? senão ser a vítima de mim mesma. Só peço a Deus que ninguém me encomende mais nada. Porque, ao que parece, sou capaz de revoltadamente obedecer, eu a inliberta.

Uma pessoa leu meus contos e disse que aquilo não era literatura, era lixo. Concordo. Mas há hora para tudo. Há também a hora do lixo. Este livro é um pouco triste porque eu descobri, como criança boba, que este é um mundo-cão.

É um livro de treze histórias. Mas podia ser de quatorze. Eu não quero. Porque estaria desrespeitando a confidência de um homem simples que me contou a sua vida. Ele é charreteiro numa fazenda. E disse-me: para não derramar sangue, separei-me de minha mulher, ela se desencaminhou e desencaminhou minha filha de dezesseis anos. Ele tem um filho de dezoito anos que nem quer ouvir falar no nome da própria mãe. E assim são as coisas.

C.L.

P.S. - "O homem que apareceu" e "Por enquanto" também foram escritos no mesmo domingo maldito. Hoje, 13 de maio, segundafeira, dia da libertação dos escravos - portanto minha também escrevi "Danúbio Azul", "A língua do "p"” e "Praça Mauá". "Ruído de passos" foi escrito dias depois numa fazenda, no escuro da grande noite.

Já tentei olhar bem de perto o rosto de uma pessoa - uma bilheteria de cinema. Para saber do segredo de sua vida. A outra pessoa é enigma. E seus olhos são de estátua: cegos. (LisPectoR, 1998, p. 11-12)

Essas linhas iniciais quase nos desconvidam a ler o livro. Para estudiosos da autora esse dado poderia servir de argumento para não estudála. Para outros estudiosos, esse mote é quase um pedido urgente para a pesquisa. Felizmente, ou infelizmente, fazemos parte do segundo grupo. Percebemos ser esse o dado essencial para delinear a leitura que pretendemos neste estudo, uma vez que a necessidade de criar uma observação no início da obra pode nos apresentar uma outra leitura possível.

Primeiro, partimos do pressuposto de que se um autor sente necessidade de dirigir-se a seus leitores justificando-se pelo livro é por- 
que ele está preocupado com a recepção de sua literatura. Portanto, torna-se essencial que nosso olhar crítico acabe por se utilizar da teoria da recepção, proposta por Wolfgang Iser.

Segundo, se esse mesmo autor - inserido num contexto cultural tem uma visão crítica sobre seu próprio livro, que antecipa a recepção de seu leitor, torna-se inquestionável que há um momento cultural abarcando tanto autor quanto leitor e esse momento deve ser por nós apreciado. Assim, utilizaremos a idéia de cultura, discutida por Terry Eagleton, traçando um paralelo com a sociedade e as principais características das produções literárias da época, para compreender a existência desse "pedido de desculpas" de Clarice Lispector.

Trata-se de um ensaio de estudo que poderia gerar discussões maiores, mas esta não é, por enquanto, nossa intenção. Estamos longe de esgotar o tema uma vez que, em se tratando de Clarice - hermética como se nos apresenta - esgotá-lo seria, no mínimo, impossível.

Os ANOS 70

A década de 1970 apresentou-se como o mais árduo período da mais duradoura das ditaduras nacionais. Em contrapartida foi ao mesmo tempo uma época de alegrias advindas da Copa do Mundo, do crescimento econômico do país e da abertura de novos empregos. Foi, principalmente, a época do aparecimento da televisão em cores e da expansão nacional das redes de televisão concedidas pelo Estado, trazendo a certeza de um controle social efetivo em cada casa que possuísse o seu aparelho transmissor (SüsSEKIND, 2004). A euforia oriunda desse momento, do "milagre brasileiro", coincidiu com os anos de chumbo instaurados pelo AI-5 em dezembro de 68 :

Os protestos eram tolerados, desde que diante do espelho. Enquanto isso, uma população convertida em platéia consome o espetáculo em que se transformaram o país e sua história. A utopia do "Brasil Grande" dos governos militares pós-64 é construída via televisão, 
via linguagem do espetáculo. Sem os media e sem público, a produção artística e ensaística de esquerda se via transformada assim numa espécie de Cassandra. Podia falar sim, mas ninguém a ouvia. A não ser outras cassandras idênticas. (SüsSEKIND, 2004, p. 24)

A cultura nacional foi solapada pela utopia do "Brasil Grande", construída na época via televisão, numa circunstância história marcada pelo fechamento político e pelo estímulo do governo ao crescimento do comércio de bens simbólicos no país. Desenvolve-se, assim, a valorização de um mercado - muito bem definido na atualidade - da chamada "cultura de massa". A difusão e o consumo dos bens culturais aparecem como definidores da política do Estado, denominando-o democrático na medida em que incentiva os canais de distribuição dos bens culturais produzidos. O mercado, enfim, torna-se o lugar no qual se exerceriam as aspirações democráticas.

A retórica ufanista do "País que vai pra frente" é ecoada pelos meios de comunicação de massa, sobretudo pela televisão que fornece a uma população politicamente amordaçada os componentes básicos de identidade nacional.

O mercado cultural torna-se, indiretamente, cerceado pelo controle do Estado, uma vez que surgem políticas de incentivos às variadas produções artísticas e culturais - numa tentativa bem sucedida de abafar a censura com ações que estimulassem as produções artísticas. $\mathrm{O}$ cenário cultural assim configurado combina, portanto, repressão, cooptação e mesmo controle do Estado sobre o processo cultural. Ainda, nas palavras de Flora Süssekind, temos um período em que "mais claramente se passa a sentir a presença de um censor ao lado da máquina de escrever. Uma espécie de Fleury das letras acompanha de perto a produção literária dos anos 1970" (2004, p. 31).

Os livros de Clarice Lispector desse período - Felicidade clandestina, Água viva, A imitação da rosa, A via crucis do corpo, Onde estivestes de noite, A vida íntima de Laura, Visão do esplendor - impressões leves, De corpo inteiro e A hora da estrela - surgem, portanto, 
no interior de um cenário cultural marcado pela hegemonia da arte de cunho comercial, que busca o público a qualquer custo numa possível tentativa de fugir dos problemas levando-o junto. Ao mesmo tempo, paralelamente à fuga, aparece também a literatura da crítica engajada.

Heloísa Buarque de Holanda define os anos 70 como marcados pela perda do poder contestatório das artes, tanto em termos estéticos quanto políticos, concluindo que as artes plásticas sofrem um boom de mercado com os leilões e a bolsa de arte determinando sua produção, que, ao transformar-se preponderantemente em rentável negócio, perde muito a sua vitalidade crítica e praticamente deixa de interessar aos setores da juventude universitária. Flora Süssekind, consonante com Holanda, acrescenta que outras preocupações da produção literária dessa época são bastante visíveis: "Preencher as lacunas de informação dos jornais e veículos de massa, aproveitar-se de seu próprio caráter artesanal e de um conhecimento prévio de seu público restrito" (2004, p. 37).

Em um contexto cultural como o dos anos 70, no qual o filão literário de maior sucesso identificava-se com a literatura-verdade, em suas várias formas de expressão, o romance-reportagem, os textos confessionais, os depoimentos político-bibliográficos, o memorialismo, Clarice parece tentar enquadrar seu livro no mercado, atendendo ao pedido da editora Artenova e aproveitando-se de sua própria experiência literária como tradutora. Porém, essa tentativa de enquadramento já sairá falha da editora e, adiantando uma recepção coberta de estranhamento do seu público, a autora cria uma literatura que precisa de "Explicação" e, principalmente, de um pedido de desculpas.

Wolfgang Iser argumenta que "o texto literário se origina da reação de um autor ao mundo e ganha o caráter de acontecimento à medida que traz uma perspectiva para o mundo presente que não está nele contida” (Iser, 1999, p. 11). A participação efetiva de Clarice não se dá, portanto, levantando bandeiras engajadas como gostaria, por exemplo, o cartunista Henfil. ${ }^{1}$ A autora acaba por ceder ao pedido do mercado 
produzindo contos que suprem as necessidades do leitor de massa e de certa maneira fogem da contestação ativa esperada de um intelectual que nem sempre está preparado, necessitado ou liberado a realizá-la.

Não é nosso interesse, neste estudo, apontar dados que provam tratar-se de um livro de estimado valor literário; esse estudo já foi realizado pela pesquisadora Vilma Arêas em Clarice Lispector com a ponta dos dedos. ${ }^{2}$ Nossa intenção, longe de esgotar o assunto, é apenas identificar como a cultura que circunda a produção de um escritor pode, muitas vezes, modificar sua obra. Afinal, como afirma Eagleton, "cultura também é uma questão de seguir regras” (2005, p. 13). Citando, ainda, Schiller, de acordo com Eagleton:

Todo ser humano individual, pode-se dizer, carrega dentro de si, potencial e prescritivamente, um indivíduo ideal, o arquétipo de um ser humano, e é a tarefa de sua vida estar em harmonia com a unidade imutável desse ideal por meio de todas as suas manifestações cambiantes. Esse arquétipo, que pode ser discernido mais ou menos claramente em todo indivíduo, é representado pelo Estado, a forma objetiva e, por assim dizer, canônica na qual toda a diversidade dos sujeitos individuais se esforça para se unir. (EAGLETON, 2005, p. 18)

O livro em estudo prova, mais uma vez, que Clarice foi uma escritora ímpar para seus contemporâneos. Toda a sua produção foi recebida com estranhamento pela crítica por não se identificar com nenhum tipo de escritura realizada na Literatura Brasileira. Parece que, ao se enquadrar - mesmo que durante uma única obra - a essa produção, ela precisou explicar ao público e a si mesma esse - quase - corte literário. Lispector pouco esteve em harmonia com o arquétipo social preconizado pelo Estado, e na única obra em que buscou esse "caminhar com" o social acabou por "caminhar contra" o individual, mostrando que nem sempre a literatura caminha tal como a cultura ideológica (EAGLETON, 2005).

Para justificar nosso interesse nesse recorte de estudo, recorremos novamente a Eagleton ao afirmar que "o que importa não são as 
obras em si, mas a maneira como são coletivamente interpretadas, maneiras que as próprias obras dificilmente poderiam ter previsto" (EAgleton, 2005, p. 81). É fascinante notar que Clarice já previa uma definição para parte da literatura que os anos 70 estavam obrigando seus escritores a produzir: "Uma pessoa leu meus contos e disse que aquilo não era literatura, era lixo. Concordo. Mas há hora para tudo. Há também a hora do lixo. Este livro é um pouco triste porque eu descobri, como criança boba, que este é um mundo-cão."

Parafraseando Süssekind, em meio a toda uma aura de pânico do desemprego, da impossível circulação do que se produz, de perder subitamente as condições de produção que, de modo problemático, o emprego estatal ao menos fornece, parece-nos que Clarice soube buscar uma forma literária de sobrevivência exigida pelo ambiente cultural e que saiu cara para sua ética literária. Não se trata apenas de contos dissonantes de sua produção e consonantes com o que a massa quer consumir - ainda que não aceite por completo nem assuma essa predileção. Trata-se, sobretudo, de uma produção resultante de um momento cultural que traçou alguns rumos da literatura brasileira nos anos 70 , criando o que nela havia de maior luxo ou o que havia de mais lixo. ${ }^{3}$

QUANDO O PROCESSO DE CRIAÇÃO É O ERRO

A via crucis do corpo teve somente uma edição em vida da autora: a de 1974, publicada pela editora Artenova. Após isso, a editora Rocco, de posse dos direitos autorais de todo o espólio de Clarice, republicou a obra apenas em 1998.

Apresentaremos uma sintética revisão dos contos, apontando a questão da sexualidade, a partir da perspectiva adotada no livro, que difere da utilizada por Clarice nas obras publicadas até a data em análise, assim como também difere do que se espera de uma literatura de cunho erótico. ${ }^{4}$ Para facilitar nossa análise, dividimos a síntese em três 
grandes blocos, apresentados nos tópicos: "Tentativas atrapalhadas", "Historinhas tentadas" e "Preenchimento de espaços".

Em seguida, para finalizar o recorte que este trabalho propõe, nas possíveis leituras da obra, relacionaremos o incômodo sentido pela autora com o momento cultural e, finalmente, com a estética da recepção.

\section{TENTATIVAS ATRAPALHADAS}

Segue o resumo dos contos que utilizam uma linguagem erotizada ao extremo. No entanto, esse extremo beira o ridículo, uma vez que está longe de excitar o leitor no sentido que busca a literatura erótica ou pornográfica, criando um desconforto pelo excesso. Por conta disso, separamos esses contos no bloco das "tentativas atrapalhadas".

\section{Miss Algrave}

Ruth Algrave é a protagonista desse conto narrado em terceira pessoa. A história se passa em Londres, como se a descentralização da narrativa amenizasse o tema abordado, uma vez que a escolha de Londres parece tão gratuita quanto se o nome da localidade fosse Rio de Janeiro ou Juiz de Fora. Ruth é, no fundo, mulher de qualquer cidade.

Solteira e sozinha, ela apresenta-se, no início do conto, como uma mulher cheia de pudores e valores tradicionais; por conta disso, cultiva o hábito de enviar cartas para revistas e jornais numa tentativa de lutar pelos bons costumes da sociedade. É capaz de criticar, por exemplo, um casal se beijando na televisão.

Achava a cunhada uma "cadela"; os animais, uns imundos; tomar banhos diários, um grande pecado; "a falta de vergonha estava no ar" e "até as crianças eram imorais"... E, portanto, vivia rodeada por suas preces e protestos. Até que um dia, deitada sozinha no apartamento, é visitada por uma coisa que se apresentou como Ixtlan. Trata-se de uma estranha descrição de um extraterrestre. E Ruth Algrave, a mulher 
cheia de recatos e medos, acaba por ter sua primeira relação sexual com um ser de outro planeta:

Seu contato era frio como o de uma lagartixa, dava-lhe calafrios. Ixtlan tinha sobre a cabeça uma coroa de cobras entrelaçadas, mansas pelo terror de poder morrer. O manto que cobria o seu corpo era da mais sofrida cor roxa, era ouro mau e púrpura coagulada. [...] Ixtlan era branco e pequeno. (1998, p. 17)

Não bastasse o inusitado da relação criada por Clarice, Ruth ficará encantada com sua própria sexualidade e, insatisfeita por descobrir que seus encontros com Ixtlan só se realizarão nas noites de lua cheia, conhece o ato da masturbação. Não agüentando mais a solidão do desejo, começa a se oferecer a homens desconhecidos. O primeiro com quem sai, um "cabeludo", quis pagá-la, ignorando a recusa de Ruth. Assim, a partir desse contato, a mulher descobre outros dons e passa a utilizá-los, percebendo que com eles lucrará muito mais do que como datilógrafa.

Passa a viver ganhando dinheiro com a satisfação das próprias vontades enquanto espera o retorno de Ixtlan: "e quando chegasse a lua cheia - tomaria um banho purificador de todos os homens para estar pronta para o festim com Ixtlan” (1998, p. 20).

O conto inicial do livro já quebra tantos tabus que é até possível esquecer a "Explicação" de Clarice e sentir um certo desconforto com essa literatura tão libertária e certamente tão avessa à produção da autora. Não podemos nos esquecer de que a década de publicação do livro, somada às décadas anteriores, não contava com tantas produções brasileiras que abordassem a temática da sexualidade. Não bastasse isso, a produção feminina estava ainda muito longe de explorar esse viés.

Tratando-se de masturbação, contato com alienígenas, liberação sexual de uma devota-carola-solitária que beira a prostituição, Clarice faz uma miscelânea de peso no conto inicial da obra. Exatamente por se tratar de uma miscelânea, não cria um texto erótico, menos ainda, pornográfico. 
O corpo

O segundo conto do livro não deixa sequer o leitor respirar após as libertações efetuadas com o primeiro. Xavier, um dos protagonistas da narrativa, é "casado" com Carmem e Beatriz. A história se inicia com uma relação sexual a três, após terem assistido ao filme $O$ último tango em Paris. Clarice troca Ixtlan por outro tema alienígena da sociedade brasileira: o ménage à trois. E, não bastasse isso, ainda explora um não assumido lesbianismo entre Carmem e Beatriz:

Às vezes as duas se deitavam na cama, longo era o dia. E, apesar de não serem homossexuais, se excitavam uma à outra, faziam amor. Amor triste.

Um dia contaram esse fato a Xavier.

Xavier vibrou. E quis que nessa noite as duas se amassem na frente dele. Mas, assim, encomendado, terminou tudo em nada. As duas choraram e Xavier encolerizou-se danadamente.

Durante três dias ele não disse nenhuma palavra às duas.

Mas, nesse intervalo, e sem encomenda, as duas foram para a cama e com sucesso. (1998, p. 23)

Não satisfeita por criar uma relação a três, com passagens pela homossexualidade e pelo voyeurismo, Clarice ainda acrescenta outro dado que sozinho geraria nova história: Xavier começa a ter um caso com uma prostituta.

Quando as mulheres descobrem, ficam tão iradas que no desfecho do conto há o assassinato de Xavier; ele é esfaqueado no escuro do quarto pelas duas esposas que "faquejaram erradamente, apunhalando o cobertor" na primeira tentativa. Quando finalmente matam o homem, decidem se desfazer do corpo enterrando-o no jardim da própria casa. Romanticamente, no local da cova, plantam uma roseira.

Deram falta do homem no serviço, a polícia foi chamada, as mulheres se entregaram mostrando a roseira e, num desfecho mais cômico do que dramático, os policiais decidem liberá-las fingindo que nada 
acontecera para não terem trabalho e "não dar muito barulho, muito papel escrito, muita falação" (1998, p. 28).

A superposição de itens que criariam uma grande história erótica (se não pornográfica), o excesso de dados e a falta de centralização em cada um deles, fazem com que a história se perca em desencontros numa superficialidade que explicita a dificuldade da escritora em explorar temática tão diferente de sua produção. Por trás de tantas citações que poderiam engendrar um belo conto erótico ou um excitante ambiente pornográfico, sente-se uma escritora perdida na obrigação de criar algo que vai muito além de seu estilo e de sua vontade.

Ele me bebeu

Aurélia Nascimento e Serjoca são, respectivamente, prostituta e homossexual que dividem o mesmo espaço. A narrativa apresenta-nos um momento em que os dois demonstram interesse pelo mesmo homem: Afonso.

Serjoca, um maquilador profissional, ganha a disputa, levandonos a outro não assumido caso de homossexualidade. Chamamos de não assumido porque, em vez de explorar a situação em que os dois homens mostram mútuo interesse, o narrador prefere focar a narrativa no desamparo de Aurélia que descobre ter sido neutralizada pelo excesso de maquiagem e pela presença do amigo homossexual. Clarice criou existencialismo num ambiente totalmente inusitado.

Ruído de passos

O narrador apresenta-nos Cândida Raposo, uma mulher de oitenta e um anos de idade, que precisa procurar um médico, pois ainda sente "o desejo de prazer". Espantada por descobrir que "a coisa" não passa nunca, como lhe explica o médico, volta para casa e tenta se arranjar sozinha. 
A cena de masturbação perde toda a sua referência pornográfica e ganha uma aura de tristeza e solidão pela forma com que é narrada:

O médico olhou-a com piedade:

- Não há remédio, minha senhora.

- E se eu pagasse?

- Não ia adiantar nada. A senhora tem que se lembrar que tem oitenta e um anos de idade.

- E... se eu me arranjasse sozinha? O senhor entende o que eu quero dizer?

- É, disse o médico, pode ser um remédio.

Então saiu do consultório. [...]

Nessa mesma noite deu um jeito e solitária satisfez-se. Mudos fogos de artifícios. Depois chorou. Tinha vergonha. Daí em diante usou o mesmo processo. Sempre triste. É a vida, senhora Raposo, é a vida. Até a bênção da morte.

A morte.

Pareceu-lhe ouvir ruído de passos. Os passos de seu marido Antenor Raposo. (1998, p. 56)

Clarice trabalha um tabu que se estende até a literatura atual: a sexualidade de pessoas idosas. E não bastasse isso, o une à masturbação e à questão sobrenatural. $\mathrm{O}$ desconforto criado pela senhora para satisfazer um desejo (que "é um inferno") é quebrado com a chegada de seu marido. Assim, o leitor é instigado a criar o desfecho da situação proposta.

\section{Praça Mauá}

Semelhante ao que acontece no conto "Ele me bebeu", em "Praça Mauá", os personagens Carla e Celsinho freqüentam o cabaré "Erótica”. Ela, Luísa na vida real - casada e com boa condição de vida prostitui-se quando quer e sente prazer na vida dupla que leva. Ele, "um homem que não era homem", é um travesti de sucesso que lhe serve de amigo e confidente. 
O estranhamento entre ambos acontece quando se interessam pelo mesmo homem, numa noite, no cabaré, e Celsinho, num acesso de fúria, grita para todos ouvirem que Carla era menos mulher do que ele, pois não sabia sequer cozinhar.

A aproximação desse conto com "Ele me bebeu" é que Carla, assim como Aurélia, passa por um momento existencialista num desconhecer-se através do outro.

\section{A língua do "p"}

Maria Aparecida é a personagem desse conto. Ela é uma professora de inglês que descobre, durante uma viagem de trem para a cidade, que seria estuprada por dois desconhecidos assentados próximos a ela.

O que diferencia esse conto de uma simples história sobre um crime de jornal é o fato de a mulher perceber o perigo que está correndo ao prestar atenção na conversa dos homens que dialogam usando a língua do "p". Ela está prestes a ser currada (termo usado no conto) por homens que recuperam a língua utilizada por crianças.

Cidinha - como a chamavam - decide se proteger fingindo ser uma prostituta e, de forma atrapalhada e estranha, acaba por afastar os homens. O conto toma então um ar de comédia, pois a personagem é notada pelo bilheteiro que a delata ao maquinista e a entrega a um policial na estação seguinte. Cidinha é retirada do trem e levada pelo policial, não deixando de ser menosprezada pelo olhar de uma mulher que entrara no trem e tomara o seu lugar no vagão.

Após três dias na prisão sendo chamada dos piores nomes é liberada e, de volta ao trem para continuar seu caminho, percebe assustada e surpresa que, naquele dia, sentira vontade de ser estuprada por aqueles dois homens: "Epe sopoupu upumapa puputapa. Era o que descobrira. Cabisbaixa” (1998, p. 70).

No Rio, enquanto esperava novo vôo para continuar sua viagem, Cidinha lê no jornal que uma moça - aquela que a desprezou en- 
quanto era levada pelos policiais - havia sido estuprada e assassinada pelos dois homens do trem no seu lugar.

\section{HISTORINHAS TENTADAS}

Com o trocadilho do título, nossa intenção é discursar a respeito da tentativa falha da escritora de criar histórias sem, no entanto, explorálas. Histórias que iniciam abordando a tentação da carne e acabam por falhar no ideal erótico a que se propõe o livro.

Via crucis

O conto é uma paródia do nascimento de Cristo a partir da história de Maria das Dores, uma mulher casada com um homem que nunca a tocara, mas que descobre estar grávida. Certa de que nada lhe acontecera, após consulta que confirma sua gravidez de três meses, a mulher decide dar o nome de Jesus a seu filho, criando sua própria "enunciação". Avisa ao marido que ele é, agora, José e resolve mudar o nome do menino para Emmanuel numa tentativa de poupar-lhe do sofrimento que Cristo havia passado.

Clarice empreende nesse conto uma inversão da história religiosa criando um ambiente em que a mulher, de posse de todo um passado referencial, resolve por conta própria repetir o caminho bíblico transformando a história sem desfecho - uma vez que o leitor já o conhece numa grande dessacralização do sagrado.

Esse conto também foi inserido no livro $O$ primeiro beijo e outros contos, publicado pela Ática, na série Rosa dos ventos, em 1989. A proposta da série, destinada a pré-adolescentes na faixa de 13 anos, é tornar acessíveis a esses leitores textos de escritores consagrados na literatura brasileira. A recepção a esse conto é positiva, apesar do tema complicado, que pode parecer vulgar. A sua inserção nessa edição vem provar o quanto o conto é falho no trato à pornografia, embora fosse essa a proposta inicial de $A$ via crucis do corpo. 
O conto também poderia inserir-se no próximo item ("Preenchimentos de espaços") uma vez que essa história já havia sido publicada, em 1973, na coluna de crônicas do Jornal do Brasil e em 1974 na obra Onde estivestes de noite.

"Antes da ponte Rio-Niterói" é o conto mais confuso de todos, como confusa pode ser uma história contada por alguém que a acabara de ouvir de outra pessoa. A linguagem nele empregada, como aponta Vilma Arêas, é a de uma história corriqueira que alguém está contando a outra pessoa e por isso há cortes e comentários só usados na língua falada. A confusão de nomes e o perder-se durante o contar fazem da história uma tentativa falha de amor e ciúme.

Baseada, como afirma Clarice na nota intitulada "Explicação", em um caso real, temos a atrapalhada história de um homem que ia se casar com Jandira, que fica paraplégica. Por piedade e para atender ao pedido da família, acaba ficando com ela, com a expectativa de que a vida dela seria curta - o que realmente acontece. A mulher morre, e solteiro novamente, esse homem, que não perdoava defeitos físicos, é atacado pela nova esposa (Leontina) numa crise de ciúme e fica surdo. Leontina vai presa e, após a sua liberação, eles ficam juntos. $\mathrm{O}$ narrador avisa não saber se "para sempre", pois não sabe que fim levaram os personagens dessa história tão confusa e incompleta.

Melhor que arder

O conto é a história de Madre Clara, uma mulher que se tornara freira por obediência à família, mas precisa abandonar o celibato, pois não suporta a iminência do desejo. Seguindo o conselho do Padre, de que é "melhor não casar. Mas é melhor casar do que arder" (LisPeCtor, 1998, p. 72), Clara procura a superiora e pede para sair do convento; ela quer encontrar um homem para casar-se. Morando sozinha numa pensão e recebendo ajuda da família, faz seus próprios vestidos e passa as 
noites rezando muito para que alguma coisa boa lhe aconteça. Numa ida a um botequim para comprar uma garrafa de água conhece o dono português e, após convites para ir ao cinema, tomar um cafezinho e dar longos passeios, ele a pede em casamento.

Seu casamento, na igreja, é realizado pelo mesmo Padre que lhe dera o conselho. Clara será feliz e mãe de quatro filhos homens.

O texto é curto, com uma seqüência narrativa de acontecimentos com começo, meio e fim. Embora Clarice tente nos apresentar uma personagem transgressiva: uma freira que sente desejos e vontade de morder a mão do padre quando ele lhe dá a hóstia, o trato superficial da história - embora narrativamente linear - não o poderia enquadrar nem em literatura erótica e menos ainda em literatura pornográfica. É como se o elemento "freira com desejos" (ainda que isso não seja falado com essas palavras) fosse suficiente para atender a encomenda da editora.

Mas vai chover

Maria Angélica de Andrade é a personagem desse conto. Como em Cândida Raposo (do conto "Ruído de passos"), a escritora nos apresenta o desejo na maturidade. A transgressão desse conto ocorre pelo fato de a mulher ter um amante de dezenove anos. Ele é entregador de produtos farmacêuticos e ela, fascinada pelo jovem, faz de tudo para conquistá-lo. Embora no século XXI essa situação não seja mais tabu na sociedade brasileira, nos anos 70 ainda não era tema confortável para ser trabalhado na literatura. Não bastasse isso, Clarice nos apresenta uma personagem que tende para o ridículo nas suas tentativas de conquistar o jovem:

- Só deixo você sair se prometer que voltará! Hoje mesmo! Porque vou pedir uma vitaminazinha na farmácia...

Uma hora depois ele estava de volta com as vitaminas. Ela havia mudado de roupa, estava com um quimono de renda transparente. Via-se a marca de suas calcinhas. Mandou-o entrar. Disse-lhe que 
era viúva. Era o modo de lhe avisar que era livre. Mas o rapaz não entendia. [...]

Levou-o a seu quarto. Não sabia como fazer para que ele entendesse. Disse-lhe então:

- Deixe eu lhe dar um beijinho!

$\mathrm{O}$ rapaz se espantou, estendeu-lhe o rosto. Mas ela alcançou bem depressa a boca e quase o devorou.

- Minha senhora, disse o menino nervoso, por favor, se controle! A senhora está passando bem? [...]

- Eu lhe dou um presente grande! Eu lhe dou um carro! [...]

O que se passou em seguida foi horrível. Não é necessário saber. Maria Angélica - oh, meu Deus, tenha piedade de mim, me perdoe por ter que escrever isto! - Maria Angélica dava gritinhos na hora do amor. E Alexandre tendo que suportar com nojo, com revolta. Tinha a impressão de que nunca mais ia poder dormir com uma mulher. O que aconteceria mesmo: aos vinte e sete anos ficou impotente. (1998, p. 76-77)

O conto termina com Alexandre exigindo que a mulher lhe dê alta quantia em dinheiro:

- Sim!, respondeu irritado, um bilhão antigo!

- Mas... mas eu não tenho tanto dinheiro...

$[\ldots]$

- Sua velha desgraçada! sua porca, sua vagabunda! Sem um bilhão não me presto mais para as suas sem-vergonhices! (1998, p. 78)

A mulher, quieta e muda, parecendo "ferida de guerra", o vê saindo, sem palavra nenhuma a dizer-lhe, pensa apenas, para surpresa do leitor: "Parece - pensou - parece que vai chover".

A situação do livro é cíclica, uma vez que a mulher desse conto é colocada na mesma situação que Ruth Algrave, da história que inicia o livro. Ruth e Maria Angélica não cabem nas histórias eróticas ou pornográficas em que são inseridas: da forma com que caminham são expostas a um ridículo não esperado de um texto que deveria excitar o leitor. 


\section{PREENCHIMENTOS DE ESPAÇOS}

Clarice escrevia crônicas para o Jornal do Brasil (1967 a 1973) e muitos pesquisadores apontaram a dificuldade com que a escritora desempenhava essa função de escrita encomendada lutando não só com a falta de inspiração, mas com a obrigatoriedade da criação. Para preencher lacunas de textos que não "brotavam", Clarice muitas vezes se utilizou de trechos de romances, conversas com leitores, respostas a cartas e fãs, preces e outros gêneros textuais que muito se distanciavam da produção tradicional de um cronista. A coluna de Clarice no jornal, que durou alguns anos e lhe rendeu um dinheiro fixo - muito importante para a escritora se manter - acabou por transformar-se em uma grande colcha de retalhos.

Conhecendo esse hábito de Clarice, de preencher espaços em branco com o que havia de próximo ou utilizável, compreendendo que a escritora - em face da necessidade - buscava o que de escrito estivesse por perto, encontramos alguns textos em $A$ via crucis do corpo que mais parecem uma tentativa de preencher espaço no livro. A narradora dos três contos desfia pensamentos e emoções, relata pequenos fatos e reflete acerca do ofício da escrita, oferecendo ao leitor a contraprova para lhe avaliar a própria escrita.

\section{O homem que apareceu}

O conto, em síntese, é uma narração em primeira pessoa do encontro de uma escritora com um homem de rua. Após convidá-lo para um café em sua casa, a narradora confirma ser este homem um antigo conhecido seu e ambos travam um desencontrado diálogo sobre temas que vão desde refrigerante até o valor da literatura:

- Você jura que a literatura não importa?

- Juro, respondi com a segurança que vem de íntima veracidade. E acrescentei: qualquer gato, qualquer cachorro vale mais do que a literatura. (1998, p. 37) 
O texto carrega a mesma linguagem de outros textos escritos por Clarice para o Jornal do Brasil, assim como apresenta detalhes e costumes típicos da vida da autora (beber café e coca-cola, fazer referências aos dois filhos, ao bairro em que residia na época).

Depois de três contos reunindo situações erotizadas de formas atrapalhadas e exageradas ("O homem que apareceu" é o quarto conto do livro), a escritora parece esgotada de idéias e utiliza-se da mesma saída de que lançava mão nos jornais: acrescenta autobiografia à sua literatura.

Por enquanto

As três páginas do conto são um quase diálogo autobiográfico. Clarice, algumas vezes, realizou esse exercício de escrita em voz alta e ficamos com a sensação de que o escritor conversa enquanto escreve: "Mas se Deus nos fez assim, que assim sejamos. De mãos abanando. Sem assunto" (1998, p. 45).

Por isso, é quase impossível sintetizar esse conto - se é que podemos enquadrá-lo nesse gênero.

Dia após dia

Esse conto, assim como os outros dois anteriores, poderia ser uma continuação da "Explicação" que abre o livro, uma vez que a narradora além de citar a data - 13 de maio - menciona que recebera o telefonema de um amigo pedindo-lhe que não escrevesse o livro:

Quando cheguei em casa uma pessoa me telefonou para dizer-me: pense bem antes de escrever um livro pornográfico, pense se isto vai acrescentar alguma coisa à sua obra. Respondi:

- Já pedi licença a meu filho, disse-lhe que não lesse meu livro. Eu lhe contei um pouco as histórias que havia escrito. Ele ouviu e disse: está bem, contei-lhe que o primeiro conto se chamava "Miss Algrave". Ele disse: "grave" é túmulo. [...] 
Mas a pessoa que me telefonou zangou-se, eu me zanguei, ela desligou o telefone, eu liguei de novo, ela não quis falar e desligou de novo.

Se este livro for publicado com mala suerte estou perdida. Mas a gente está perdida de qualquer jeito. Não há escapatória. [...]

Pois é. Sei lá se esse livro vai acrescentar alguma coisa à minha obra. Minha obra que se dane. Não sei por que as pessoas dão tanta importância à literatura. E quanto ao meu nome? que se dane, tenho mais em que pensar. (1998, p. 50)

Ou seja, discursa a respeito da própria obra que, tendo sido programada para fracassar, não só cumpre bem seu papel fracassando como precisa ser ressignificada e desculpada a todo momento.

\section{OS NOMES DAS PERSONAGENS FEMININAS}

É importante reiterar uma característica que apontamos na obra: ao transformar Marias em mulheres que desejam, percebemos uma tentativa de transgredir, uma vez que a escritora ressignifica os nomes ao mesmo tempo em que cria intertextualidades. O leitor, surpreso, acaba por deparar com mulheres que na literatura representavam um signo diferente do apresentado por Clarice.

As personagens bíblicas

Ruth, uma personagem bíblica, representa a história da mulher viúva que casa com o irmão do marido dando continuidade à tradição familiar. O significado do nome, além de plena de beleza, é amiga.

A Ruth, de "Miss Algrave", é amiga de Jack, primo com quem brincava na infância, na cama grande da vovó, de marido e mulher, fazendo de tudo para ter filhinhos. Ruth será amiga de Ixtlan e de todos os outros homens com quem se relacionará após a descoberta do sexo.

Nos contos "A via crucis do corpo", "A língua do "p"” e "Mas vai chover", as três mulheres chamam-se Maria, alusão clara à mãe de Cristo. 
A primeira, Maria das Dores, está no conto que parafraseia o nascimento de Cristo. O nome composto da personagem mostra, explicitamente, o papel dessa mulher: carregar o sofrimento de ser a mãe do filho de Deus.

A segunda, Maria Aparecida, está no conto da mulher que será estuprada por dois homens. A forma de defesa dela? Parecer quem não é, tornar-se evidente, revelada, notada, aparecida.

Aúltima, Maria Angélica, é a mulher do conto "Mas vai chover", e, paradoxalmente ao que um ser angelical poderia revelar, é a senhora de 60 anos que ataca o jovem com beijos e promessas, tornando-se, como já definimos, a expressão do grotesco e do ridículo.

A personagem Clara, de "Melhor que arder", faz movimento contrário ao de Santa Clara. Enquanto a santa católica entra para a igreja contra a vontade dos pais, a de Clarice o faz por imposição da família. Mas acaba saindo, para decepção de todos. Enquanto a primeira faz o voto de pobreza e vive um estilo de vida contemplativo (enclausurada e sem contato com o povo) a personagem de Clarice vai se casar com um homem de posses e ter quatro filhos.

As personagens literárias

Beatriz é um nome muito importante para o escritor Dante Alighieri. Fonte de inspiração em quase todas as suas obras é retratada como símbolo de pureza e perfeição. Na Divina Comédia, Beatriz é símbolo do amor divino ou da religiosidade. É ela que chama Virgílio (a razão) para guiá-lo para fora da selva. No conto "O corpo" Beatriz é a mulher rancorosa. Carmem, nome que significa poema, verso, poesia, é a que mantém um diário e compra uma máquina de escrever na viagem que fizeram a Montevidéu, é portanto aquela que produz arte. Ela é também a mais colérica e a que comanda o assassinato de Xavier. A relação entre as duas mulheres, de cumplicidade e subordinação, corresponde também ao peso que seus nomes representam. Beatriz, no conto, é guiada por Carmem, uma vez que é a mais pura e dócil. 
Jandira também é nome de personagem de Nelson Rodrigues, no conto "Sem caráter", da coluna A vida como ela é... publicada no jornal Última Hora, do Rio de Janeiro, no período de 1951 a 1961. Nelson Rodrigues escreveu diariamente um conto diferente que envolvia casamento, paixão e desejo, mas tinha como assunto principal sempre o mesmo tema: o adultério feminino. Justamente pelo tema tratado, "A vida como ela é..." consolidou a reputação de "tarado" do escritor e lhe deu enorme popularidade.

Como afirma Beatriz Polidore, ${ }^{5}$ pesquisadora da UFSC, em estudo sobre essa coluna de Nelson Rodrigues:

Quando a coluna $A$ vida como ela é... foi criada, os contos tinham correspondência em acontecimentos reais e saíam junto à seção de crimes do vespertino, trazendo o nome e a foto dos envolvidos. Em poucos dias as histórias perderam esse caráter de verdade, dando maior liberdade ao escritor, que passou a inventá-las. Com o tempo aconteceram outras mudanças, as histórias deixaram de ser extremamente trágicas para se tornarem mais cômicas, o que provavelmente ocasionou a mudança de lugar da coluna no jornal. Nesses contos as tramas se desenvolvem em função das infidelidades femininas ou das possibilidades de infidelidades proporcionadas pelo forte desejo das protagonistas por homens que não eram seus maridos. Os finais das histórias variavam entre a tragédia (quando as traições femininas resultavam em morte da mulher, do marido ou do amante) e a ironia (quando a situação final do conto tendia para a comicidade, como, por exemplo, quando marido, mulher e amante passavam a conviver em harmonia). (Polidore, 2008, p. 1)

O conto de Clarice enquadra-se no mesmo perfil dos contos apresentados na coluna, embora, de forma atrapalhada. Mas o que o sustenta (crime, infidelidade, subversão) é a mesma temática que sustenta os contos de Nelson Rodrigues. Não é à toa que o nome escolhido cria essa intertextualidade. 
As personagens de nome

Embora Aurélia seja também nome importante na literatura, uma vez que é forte personagem feminina de José de Alencar na obra Senho$r a$, vemos no conto "Ele me bebeu" mais relação entre a construção da personagem de Clarice com o significado do próprio nome. Aurélia significa aquela que é dourada, de ouro. No conto, logo no terceiro parágrafo, ela é descrita como "bonita e, maquilada, ficava deslumbrante. Era loura, usava peruca e cílios postiços. [...] Sua boca era um botão de vermelha rosa. E os dentes grandes, brancos" (1998, p. 41). Ou seja, a personagem, tal como o nome representa, é uma mulher deslumbrante e notável, mas que será "bebida" pelo personagem Serjoca para, depois de ser apagada pelo maquilador, se encontrar no espelho, ao final do conto, fazendo jus ao sobrenome: "no espelho viu enfim um rosto humano, triste, delicado. Ela era Aurélia Nascimento. Acabara de nascer. Nas-ci-men-to".

É fascinante o paradoxo que envolve a personagem Cândida Raposo no conto "Ruído de passos", pois, a princípio, esperamos da personagem a inocência e pureza que se atribui a uma mulher dessa idade, não importa a vida que tenha levado. Não bastasse isso, ela ainda possui o nome de Cândida, o que nos leva, novamente, à questão da pureza, mas o conto nos surpreende com o oposto, representado pelo sobrenome Raposo, identificando-nos uma personagem que não cessa de desejar e precisa solitariamente se satisfazer.

Clarice/Cultura: R(D)ecepÇão

Literature, so far as it is Literature, is an "apocalypse of Nature", a revealing of the "open secret".

CARLYle

Wolfgang Iser afirma, em seu estudo $\mathrm{O}$ ato da leitura, que os textos ficcionais, geralmente, respondem a situações de sua época, “à 
medida que produzem algo que está condicionado pelas normas vigentes, mas que já não pode mais ser captado por ela" (IsER, 1999, p. 23). Dentro do corpus literário de Clarice é interessante o quanto o livro em questão responde a esse conceito de Iser, uma vez que apresenta-nos uma obra totalmente presa à produção cultural da época, mas que nos adianta uma discussão atual a respeito da literatura. Como vimos na introdução deste trabalho, a literatura produzida nos anos 70, no Brasil, configurou-se numa resposta social a dois caminhos específicos: o de respeito à voz da censura, produzindo aquilo que era permitido e/ou exigido e o de oposição velada. A via crucis do corpo pertence ao primeiro caso, como a própria "Explicação" presente na obra elucida. Não bastasse ser uma literatura totalmente divergente da produzida pela escritora, é também uma literatura que não cabe na própria tentativa de nomeá-la. Não podemos chamar os contos de eróticos porque, no excesso, acabam por pecar negativamente, apresentando-nos muito mais a tristeza e as ansiedades sexuais de seus personagens do que a excitação da libido que se espera desse tipo de literatura. Não podemos chamá-los de contos pornográficos porque tampouco revelam ou exploram o tema como deve fazer esse tipo de literatura. Não se pode inserir o livro na literatura pornográfica porque, a primeira característica que a define, ele não contempla. Afinal, não há, como se espera nesse gênero, a utilização de uma linguagem que nomeia, que descreve posições sexuais, partes do corpo, relações entre pessoas de modo explícito. Assim como também não há o claro, o desdobrado, e sim, na maioria das vezes, a insinuação. Quando a autora utiliza o explícito, ela acaba por transformá-lo em ridículo ou por pedir desculpas no próprio ato da escrita. Como acontece no conto "Mais vai chover", em que a narradora, antes de descrever o orgasmo de Maria Angélica, pede desculpas ao leitor. Não podemos chamá-los de contos existenciais, estilo com o qual Clarice se tornou conhecida e representante da literatura brasileira, porque apenas superficialmente insinuam transformações de seus personagens, sem deixar que eles, 
assim como Lóri, G.H. ou Martim, deslizem pelo que há de intenso e hermético dessa literatura. Sequer podemos chamá-los de contos, se utilizarmos os necessários critérios de qualificação do gênero. É um livro, cuja única classificação encontrada pela própria autora foi "lixo".

A obra lhe saiu cara, como vimos num dos contos que narra o desencontro entre a narradora em primeira pessoa e um amigo que lhe telefonara pedindo que não publicasse um livro pornográfico. ${ }^{6}$ Parece que a escritora pagou caro por algo que sequer conseguira realizar. Vilma Arêas cita o que a crítica deixou escapar dentro do quase silêncio com que a obra foi recebida: ${ }^{7}$

Compreendido como puro divertimento, o que não deixa de ser, e de mau gosto, o que é muito discutível, $A$ via crucis do corpo passou despercebido à análise - com exceção da demolição sistemática e moralista que sofreu. A preocupação de Clarice era real: "Se este livro for publicado com 'mala suerte' estou perdida", afirma (p. 64). Acho que mala suerte era para não dizer outra coisa. Portanto, ele pode servir de exemplo quanto à definição de uma esfera cultural dura, porque sem complexidade e sem saber lidar com matizes ou alternativas.

De qualquer modo, $A$ via crucis do corpo ilumina com crueza a limitação desse espaço e do lugar assegurado aos escritores difíceis de serem alinhados, sem habilidade de se adequarem aos novos tempos. $(2005$, p. 72$)$

Acrescentaríamos aqui, ao comentário de Arêas: "sem habilidade de se adequarem aos novos tempos", mas tentando.

O que nos fascina e intriga é o quanto um momento cultural, gerado por um espaço histórico e político, sem sombra de dúvidas, caótico, pode não só descarrilar como sufocar a literatura de um escritor.

Clarice mostra-se consciente do que é esperado dela enquanto escritora paga, e mostra-se ainda mais consciente da sua incapacidade de realizar o que dela esperam. Todo esse processo em que foi gerado o livro cria na escritora uma urgente necessidade de explicar-se: no primeiro texto "Explicação" e no oitavo conto "Dia após dia", principal- 
mente. Iser aponta que uma das estéticas mais preocupadas com a recepção do público seria a pop art:

Sempre que uma obra de arte usa efeitos exagerados de afirmação, esses efeitos cumprem uma finalidade estratégica, mas não constituem o próprio tema. Sua função é de fato negar o que aparentemente afirmam. (Iser, 1999, p. 37)

Clarice Lispector, tal como ocorre na pop art, parece estruturar a erotização de sua obra da forma mais exagerada possível - afinal, era o que a Artenova dela encomendara - e, tal como Iser aponta, acaba por negar a própria pornografia e, de quebra, a erotização que o leitor espera da obra. Até porque, a superposição de elementos eróticos e/ou pornográficos se dá de forma tão over que cria muito mais um incômodo do que uma satisfação.

Essa ruptura literária empreendida por Clarice, quando em sua tentativa de responder ao que a estética da época esperava dela, acaba por nos mostrar uma possibilidade de experimentar na leitura o espírito da época, as condições sociais e as disposições da autora.

Hour OF TRASH: ORDERED LITERATURE OF ClaRice LisPeCtOR

\section{ABSTRACT}

This article aims to discuss the construction and reception of the book $A$ via crucis do corpo, written by Clarice Lispector, using, for that, the concept of culture adopted by Terry Eagleton. The work intends to point out how much the book differs from the writer's production, in an attempt to adapt itself to a specific cultural moment.

KEY WORDS: Literature, culture, Clarice Lispector.

\section{NOTAS}

1 Trata-se de uma tirinha publicada por Henfil nos meios de comunicação da época, em que o cartunista critica pensadores que não se mostravam 
engajados nas causas sociais. Clarice, considerada alienada por ele, é enterrada em uma de suas tirinhas.

2 Vilma Arêas, no ensaio "Com a ponta dos dedos: a via crucis do corpo", inserido em seu livro já citado, faz a seguinte pergunta: "teria Clarice negado a radicalização e o projeto de busca de sua arte, como sugere a palavra irritada da crítica jornalística e o silêncio dos acadêmicos?" (ARÊAS, 2005, p. 53). No ensaio, a pesquisadora sugere, de forma muito interessante, que os contos são de grande valor literário e não só continuam como antecipam discussões da esfera da produção de Clarice. É uma crítica que aponta leituras inteligentes e novas da obra e que, portanto, para nós, supre qualquer discussão que se possa querer - neste momento - traçar a respeito do valor estético da obra em questão.

3 Ao adotarmos a nomenclatura "lixo" para esse trabalho específico da autora, não queremos qualificá-lo como uma produção ruim. Afinal, concordamos com Arêas que $A$ via crucis do corpo é uma grande obra de Clarice. Adotamos o qualificativo mais por conjeturarmos que um momento cultural pode, muitas vezes, obrigar um escritor a criar algo que não lhe é agradável, mas que não é necessariamente bom ou ruim. Até porque bom e ruim são juízos de valor que não queremos trabalhar neste ensaio.

4 Existe uma linha divisória entre o que é erótico e o que é pornográfico, como bem aponta Umberto Eco. "Uma vez me perguntaram como é que alguém poderia determinar cientificamente se um filme é pornográfico ou não. Um moralista diria que um filme é pornográfico se contém cenas explícitas e minuciosas de atos sexuais. Mas em muitos processos por pornografia demonstrou-se que algumas obras de arte contêm esse tipo de cena em função de propósitos realísticos (mostrar a vida como ela é) ou éticos (condenar a sensualidade apresentada) e que, de qualquer modo, o valor estético da obra como um todo redime a obscenidade das partes. [...] Um filme pornográfico deve satisfazer o desejo que o público tem de ver cenas de sexo explícito, mas não pode ficar uma hora e meia mostrando sexo sem parar, pois isso seria cansativo para os atores - e em última instância também para a platéia. Assim, é preciso distribuir os atos sexuais ao longo da história. Entretanto, ninguém tem a menor intenção de investir tempo e dinheiro numa história razoável, nem os espectadores têm o menor interesse na história porque só estão ali esperando as cenas de sexo" (ECO, 1994, p. 67-68). Na perspectiva adotada neste trabalho, não nos interessa explorar 
as diferenças do termo. Embora (e por isso a longa citação) entender o que é pornografia seja importante para compreender a razão de ser o livro apontado como uma produção falha de Clarice.

5 O estudo "A fidelidade feminina em questão: um estudo de contos da coluna A vida como ela é... de Nelson Rodrigues", de autoria de Beatriz Polidore pode ser encontrado no site: http://www.fazendogenero7.ufsc.br/artigos/B/ Beatriz_Polidori_Zechlinski_13_C.pdf. Último acesso em 25 jan. 2008.

6 É interessante notar que os termos "erótico" e "pornográfico" criam certa confusão. A editora pediu que ela fizesse um livro erótico, porém o amigo, quando lhe telefona, utiliza o termo pornográfico. Só a delimitação dos termos e a caracterização real do livro entre um e/ou outro daria por si só assunto para outro trabalho.

7 A título de comentário e curiosidade, Alfredo Bosi, em História concisa da literatura brasileira (1994), ignora o livro no verbete destinado a Clarice. Cita toda a sua produção literária, menos $A$ via crucis do corpo (ver BosI, 1994, p. 423). Já Massaud Moisés, em História da literatura brasileira (2001), cita o livro na cronologia, mas o ignora na revisão literária que faz ao falar das obras de Clarice (ver MoIsés, 2001, p. 340-348).

\section{REFERÊNCIAS}

ArêAS, Vilma. Clarice Lispector com a ponta dos dedos. São Paulo: Companhia das Letras, 2005.

Bosi, Alfredo. História concisa da literatura brasileira. São Paulo: Cultrix, 1994.

Eagleton, Terry. A idéia de cultura. São Paulo: Unesp, 2005.

Eco, Umberto. Seis passeios pelos bosques da ficção. São Paulo: Companhia das Letras, 1994.

Holanda, Heloísa Buarque de et al. 70/80 cultura em trânsito: da repressão à abertura. Rio de Janeiro: Aeroplano, 2000.

. O estranho horizonte da crítica feminista no Brasil. In: SüsseKIND, F. et al. (Orgs.). Vozes femininas: gênero, mediações e práticas da escrita. Rio de Janeiro: 7letras/Fundação Casa de Rui Barbosa, 2003.

IsER, Wolfang. $O$ ato de leitura: uma teoria do efeito estético. São Paulo: Editora $34,1999,2 \mathrm{v}$. 
LispeCtor, Clarice. O primeiro beijo \& outros contos. São Paulo: Ática, 1989. . A via crucis do corpo. Rio de Janeiro: Rocco, 1998.

Morsés, Massaud. História da literatura brasileira: modernismo. São Paulo: Cultrix, 2001.

Polidore, Beatriz. A fidelidade feminina em questão: um estudo de contos da coluna A vida como ela é... de Nelson Rodrigues. Disponível em: http:// www.fazendogenero7.ufsc.br/artigos/B/Beatriz_Polidori_Zechlinski_13_C.pdf. Acesso em: 25 jan. 2008.

Süssekind, Flora. Literatura e vida literária: polêmicas, diários \& retratos. Belo Horizonte: UFMG, 2004. 